\title{
Are peptide conjugates the golden therapy against obesity?
}

\author{
S J Brandt'1,2, M Kleinert',2, M H Tschöp1,2,3 and T D Müller ${ }^{1,2}$ \\ ${ }^{1}$ Institute for Diabetes and Obesity, Helmholtz Diabetes Center, Helmholtz Zentrum München, German Research Center for Environmental Health \\ (GmbH), Neuherberg, Germany \\ ${ }^{2}$ German Center for Diabetes Research (DZD), Neuherberg, Germany \\ 3Division of Metabolic Diseases, Technische Universität, Munich, Germany
}

Correspondence should be addressed to T D Müller: timo.mueller@helmholtz-muenchen.de

\section{Abstract}

Obesity is a worldwide pandemic, which can be fatal for the most extremely affected individuals. Lifestyle interventions such as diet and exercise are largely ineffective and current anti-obesity medications offer little in the way of significant or sustained weight loss. Bariatric surgery is effective, but largely restricted to only a small subset of extremely obese patients. While the hormonal factors mediating sustained weight loss and remission of diabetes by bariatric surgery remain elusive, a new class of polypharmacological drugs shows potential to shrink the gap in efficacy between a surgery and pharmacology. In essence, this new class of drugs combines the beneficial effects of several independent hormones into a single entity, thereby combining their metabolic efficacy to improve systems metabolism. Such unimolecular drugs include single molecules with agonism at the receptors for glucagon, glucagon-like peptide 1 and the glucose-dependent insulinotropic polypeptide. In preclinical studies, these specially tailored multiagonists outperform both their mono-agonist components and current best in class anti-obesity medications. While clinical trials and vigorous safety analyses are ongoing, these drugs are poised to have a transformative effect in anti-obesity therapy and might hopefully lead the way to a new era in weight-loss pharmacology.

\author{
Key Words \\ - peptides \\ diabetes \\ - obesity \\ - metabolism
}

\section{Introduction}

Obesity is a devastating condition of pandemic dimensions. In 2015, there were 107.7 million obese children and 603.7 million obese adults worldwide (Afshin et al. 2017), and this number is expected to rise. Overweight and obesity are associated with a number of comorbidities, most importantly type 2 diabetes (T2DM), cardiovascular disease, hypertension, dyslipidemia and several kinds of cancer, predominantly gastrointestinal (GI). In 2015, around 4 million deaths were attributed to overweight and obesity (Afshin et al. 2017).
Hypothetically speaking, obesity could be prevented simply by reducing food intake and increasing physical activity. However, adherence to lifestyle interventions such as regular exercise is poor. A number of psychological and economic factors are involved in such compliance, and humans might be evolutionarily predisposed to a positive energy balance (Wells 2006). Furthermore, once excess weight has been gained, human metabolism intrinsically defends against its loss (MacLean et al. 2015).

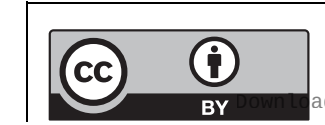


Since lifestyle interventions have so far proven insufficient to combat our obesity pandemic, other interventions are needed. To date, the most effective and long-lasting intervention is bariatric surgery. Of the various types of bariatric surgeries available, Roux-en- $Y$ gastric bypass and biliopancreatic diversion/duodenal switch surgeries are the most common and successful, with reported initial excess weight reduction of up to $68-70 \%$, where excess weight is defined as the difference between total preoperative weight and ideal weight (Buchwald 2002, Buchwald et al. 2004). Despite unquestionable effectiveness, bariatric surgery is typically only available to a small subset of individuals, with inclusion criteria being a BMI greater than 40 or greater than 35 with a comorbidity such as diabetes or heart disease (1992). In addition, the surgery itself is costly and not without risk (Chang et al. 2014).

Notably, improvement of glycemic control by bariatric surgery is rapid and is often observed even before a clinically relevant weight loss (Pories et al. 1995, Peterli et al. 2009, Bayham et al. 2012). Despite intense scientific investigation, changes in metabolic rate or intestinal nutrients absorption do not seem to explain the efficacy and sustainability in weight reduction (Olbers et al. 2006, Odstrcil et al. 2010, Carswell et al. 2014, Munzberg et al. 2015, Schmidt et al. 2016). Changes in food intake are frequently reported after bariatric surgery and are commonly considered a causal factor for the weight loss
(Brolin et al. 1994, Sjostrom et al. 2004, Laurenius et al. 2012, Munzberg et al. 2015). Notably, such differences in food intake do not seem to rely on physical limitations of the GI tract (Ryan et al. 2014), but rather result from changes in food preference, taste perception and modifications in the central food reward system (Scruggs et al. 1994, Burge et al. 1995, Miras \& le Roux 2010, Shin \& Berthoud 2011, Mathes \& Spector 2012, Laurenius et al. 2013). It seems fair to hypothesize that such changes are likely mediated via neuronal and/or humoral factors (Clemmensen et al. 2017). For example, following Rouxen-Y gastric bypass, gastric banding or sleeve gastronomy, there is an increase in the secretion of glucagon-like peptide 1 (GLP-1) (Laferrere 2016, Meek et al. 2016, Clemmensen et al. 2017), which is known not only for its beneficial effects on glycemia but also for its ability to decrease body weight via CNS-induced inhibition of food intake (Sisley et al. 2014).

GLP-1 is secreted by the intestinal L-cells in response to nutrient stimuli. GLP-1 directly acts on the $\beta$-cells to increase glucose-stimulated insulin secretion and also through the central nervous system to decrease food intake (Fig. 1) (Muller et al. 2017). Native GLP-1 is rapidly degraded by dipeptidyl peptidase IV (DPP-IV), which cleaves native GLP-1 at the N-terminal alanine at the second position, resulting in the generation of the inactive GLP- $1_{9-36 a m i d e}$ or GLP-1 $1_{9-37}$ (Mentlein et al. 1993, Deacon et al. 1995, Kieffer et al. 1995). Native GLP-1

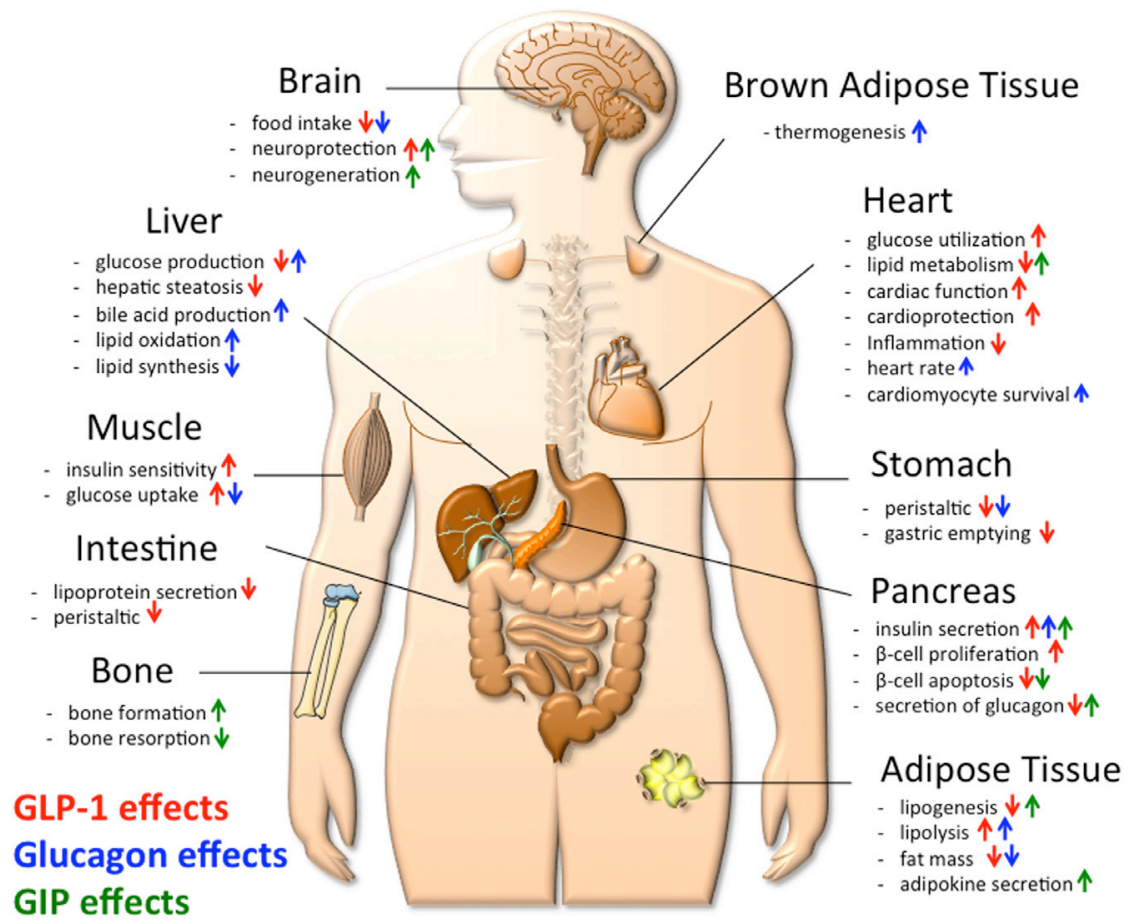

\section{Figure 1}

Schematic demonstrating the qualitative metabolic effects of GLP-1 (red arrows), glucagon (blue arrows) and GIP (green arrows) on systems metabolism, including key metabolic tissues. Arrows pointing upwards indicate an increase or improvement, while arrows pointing downwards indicate a decrease. 
accordingly has a circulating half-life of $1.5-5$ min (Hui et al. 2002, Baggio \& Drucker 2007). Modifications to the native GLP-1 sequence have overcome this limitation. Common modifications include the substitution of a d-Serine or aminoisobutyric acid (Aib) residue at position 2 to increase resistance to peptidase degradation. Another common modification is extension of the peptide to include the nine amino acid C-terminal extension (CEX) of exendin-4, which stabilizes the secondary structure and can (depending on the peptide) improve glucagon receptor agonism (Neidigh et al. 2001, Li et al. 2007, Chabenne et al. 2010, Finan et al. 2013, 2015a,b). Additional modifications such as site-specific acylation or conjugation with large biomolecules have resulted in a series of commercially available GLP-1 analogs, with varying efficacies (Finan et al. 2015a,b). Despite the development of several iterations, these GLP-1 analogs only have modest weight-lowering efficacy, which, depending on dose and duration of treatment, typically fall in the range of $1-5 \mathrm{~kg}$ (Bush et al. 2009, Nauck et al. 2009, 2016, Bergenstal et al. 2010, Fonseca et al. 2012, Meier 2012, Russell-Jones et al. 2012, Rosenstock et al. 2013, Woodward \& Anderson 2014, Davies et al. 2015, Lau et al. 2015, Thompson \& Trujillo 2015, Dungan et al. 2016, Pratley et al. 2018). Side effects such as nausea and GI distress preclude higher doses to drive greater weight loss. Therefore, it is clear that while GLP-1 analogs are beneficial to improve glycemia, targeting solely the GLP-1 receptor for the purpose of lowering body weight has limitations.

Serendipitously, native GLP-1 shows high sequence homology to glucagon and the glucose-dependent insulinotropic polypeptide (GIP). High sequence homology is also present in the receptors for GLP-1, glucagon and GIP, which together makes these peptides inherently prone to sequence hybridization for the purpose of simultaneously activating their receptors with only one molecule. Notably, glucagon can decrease body weight via inhibition of food intake and elevation of energy expenditure (Muller et al. 2017). Consequently, it was believed that such a single molecule with dual agonism at the receptors for glucagon and GLP-1 would lead to complementary (and ideally synergistic) pharmacological action, putatively driving greater weight loss and glycemic benefits through non-redundant signaling pathways. Any observed beneficial action would naturally create hope for the possibility of lower dosing schemes, thus potentially reducing the possibility of side effects, such as those typically seen at high doses of GLP-1.

$$
\text { http://joe.endocrinology-journals.org }
$$

The unimolecular formulation has several advantages compared to the loose adjunct administration of the single peptides. The key biological difference is that each independent peptide would have its specific and potentially unique pharmacokinetic profile. Accordingly, the peptides in such a loose combination would likely differ in their rates of absorption, distribution, metabolism and clearance. In contrast, a unimolecular multiagonist would have only one pharmacokinetic profile, which was hypothesized to result in superior metabolic benefits compared to a loose co-mixture of the single peptides. Furthermore, in terms of practicality, a single molecule polyagonist can more easily achieve regulatory approval.

\section{GLP-1/glucagon co-agonism}

The combination of GLP-1R and glucagon receptor (GCGR) agonism into a single entity seems, at first glance, counter-intuitive. Glucagon raises blood glucose levels by stimulating gluconeogenesis and glycogenolysis (Fig. 1) (Muller et al. 2017). In an obese patient, for whom diabetes is a liability or comorbidity, raising blood glucose would obviously be undesirable. Glucagon has indeed been postulated to play a key role in the development of type 2 diabetes (Unger \& Cherrington 2012) and patients with T2DM are frequently reported to have postprandial hyperglucagonemia due to impaired glucose inhibition of glucagon secretion (Muller et al. 1970, Unger et al. 1970, Gerich et al. 1976, Felig et al. 1978, Butler \& Rizza 1991, Kelley et al. 1994). However, glucagon also increases satiety after a meal and increases energy expenditure in rodents and humans (Muller et al. 2017). The logic behind a dual agonist targeting the receptors for GLP-1 and glucagon was thus that the insulinotropic effects of GLP-1 would buffer against any hyperglycemic liability of glucagon, while the anorectic effect of GLP-1 would synergize with glucagon's anorectic and thermogenic effects to ultimately drive weight loss (Fig. 2). One can argue that mother nature developed the first of such GLP-1/glucagon dual-agonists with oxyntomodulin (OXM). Notably, however, despite having activity at both cognate receptors, OXM greatly favors GLP-1R over GCGR (Pocai 2014).

The first patented and preclinically evaluated GLP-1/ glucagon dual agonist was developed by the groups of Richard DiMarchi and Matthias Tschöp. The molecule is based on the glucagon sequence, with key GLP-1 residues introduced to impart GLP-1R agonism (Day et al. 2009). This dual agonist also includes an Aib residue at position 2 to protect from DPP-IV cleavage. A $40 \mathrm{kDa}$ PEGylation

This work is licensed under a Creative Commons
Attribution 4.0 Unported License.






Figure 2

Schematic demonstrating the working principle, metabolic effects and key target tissues of the GLP-1/glucagon dual agonist, with the size of the text weighted to indicate the magnitude of the observed effect. Arrows pointing upwards indicate an increase or improvement, while arrows pointing downwards indicate a decrease. This dual agonist most prominently affects body weight. was added on cysteine 24 to prolong in vivo action, and a lactam bridge between Glu16 and Lys20 was introduced to stabilize the secondary structure of the molecule and to boost GCGR activity (Day et al. 2009). In DIO mice monitored for 7 days, a single injection of $325 \mathrm{nmol} / \mathrm{kg}$ resulted in a decrease in food intake and a body weight loss of 25\%, primarily due to a loss of fat mass (Day et al. 2009). In a more chronic setting, weekly administration of $70 \mathrm{nmol} / \mathrm{kg}$ of the co-agonist for 1 month resulted in a $28 \%$ decrease in body weight, primarily fat mass, as well as an improvement in glucose tolerance, an increase in energy expenditure and an increase in the utilization of lipids as energy substrates (Day et al. 2009). A 27-day study of the same dose revealed that the co-agonist decreases plasma triglycerides, LDL cholesterol and total cholesterol, decreased circulating leptin and normalized liver lipid content (Day et al. 2009). These preclinical results demonstrated the multifaceted 'approach' of the co-agonist, which robustly corrects obesity and improves multiple aspects of metabolism simultaneously.

Another example of a GLP-1R/GCGR co-agonist was developed by the research group of Merck. This co-agonist was inspired by the native hormone OXM. In order to boost the activity and efficacy of OXM, d-Serine was substituted at position 2 and a cholesterol moiety was added to the C-terminus of the peptide (Pocai et al. 2009). The resulting DualAG peptide showed nearly balanced potency at the receptors for GLP-1 and glucagon (Pocai et al. 2009). In DIO mice, every-other-day subcutaneous injections of $1.9 \mu \mathrm{mol} / \mathrm{kg}$ of DualAG for 14 days resulted in a $30 \%$ reduction in food intake and a $25 \%$ body weight loss, primarily due to a loss of fat mass (Pocai et al. 2009). In addition, DualAG induced significant improvements in glucose tolerance and normalized blood glucose levels, benefits that are likely secondary to the loss of body weight (Pocai et al. 2009). These effects were blunted in either GLP-1R ${ }^{-1-}$ or GCGR ${ }^{-1-}$ mice (Pocai et al. 2009), demonstrating the contribution of both receptors to the metabolic effects and emphasizing the importance of dual agonism for synergistic effects.

A third example of a GLP-1R/GCGR co-agonist has been developed by Sanofi. This peptide is based on the exendin-4 sequence with additional glucagon residues introduced to enhance activity at the GCGR (Evers et al. 2017). Like many of the other dual-agonists, this peptide incorporated a d-Serine at position 2 to reduce peptidase degradation, and a palmitic acid at a Lys14 to extend the half-life, which was measured to be $3.2 \mathrm{~h}$ in healthy mice (Evers et al. 2017). In DIO mice, a twice-daily subcutaneous injection of $50 \mu \mathrm{g} / \mathrm{kg}$ of this dual agonist over the course of 33 days resulted in a $29.1 \%$ drop in body weight, greater than the $13.6 \%$ drop in body weight from a matched dose of liraglutide (Evers et al. 2017). Similarly, in db/db mice, twice-daily subcutaneous injections of $50 \mu \mathrm{g} / \mathrm{kg}$ of the dual agonist over the course of 32 days resulted in lower HbA1c levels than control animals (Evers et al. 2017).

A fourth GLP-1/GCGR co-agonist (MEDI0382) is under development by MedImmune. This peptide has balanced activity at both receptors and increased stability against peptide degradation (Henderson et al. 2016). 
The half-life of this dual agonist is further enhanced by palmitoylation at Lys10, which promotes binding to serum albumin. In DIO mice, acute administration of $10 \mathrm{nmol} / \mathrm{kg}$ suppresses food intake and improves glucose tolerance, although these effects are absent in GLP-1R knockout mice (Henderson et al. 2016). In a more chronic setting, a daily dose of $30 \mathrm{nmol} / \mathrm{kg}$ of MEDI0382 results in a $30 \%$ decrease in body weight and suppression of food intake over the course of 4 weeks (Henderson et al. 2016). In a separate study, 3 weeks of $10 \mathrm{nmol} / \mathrm{kg}$ resulted in a greater weight loss than pair fed controls, and an increase in oxygen consumption and decrease in the respiration exchange ratio compared to vehicle controls, all without a difference in locomotor activity (Henderson et al. 2016), suggesting an energy expenditure component to the observed weight loss. Importantly, the weight-loss effects of MEDI0382 translate into cynomolgus monkeys. In a 29-day study with doses between 8 and $27 \mathrm{nmol} / \mathrm{kg}$ MEDI0382, cynomolgus monkeys dose dependently lost between 5 and 13\% of their body weight (Henderson et al. 2016). This weight loss was accompanied by a reduction in food intake (Henderson et al. 2016). After treatment cessation, monkeys that had been treated with MEDI0382 stabilized at a lower body weight than the control monkeys (Henderson et al. 2016), perhaps indicating that MEDI0382 induced a lower 'set point' for body weight maintenance. In a separate study, 29 days of administration of $4-27 \mathrm{nmol} / \mathrm{kg}$ in cynomolgus monkeys did not affect blood glucose (Henderson et al. 2016).

These are just some of the GLP-1R/GCGR coagonists currently in development, and several of these peptides have progressed to Phase I and Phase II clinical testing

Table 1 Multiagonists in development.

\begin{tabular}{lll}
\hline Target receptors & Drug & HM12525A \\
\cline { 1 - 2 } GLP-1R/GCGR & JNJ-54728518 \\
& MEDI0382 \\
& MK-8521 \\
& NN9277 \\
& MOD-6030/1 \\
& SAR425899 \\
& VPD-107 \\
& TT-401 \\
& ZP2929 \\
& CPD86 \\
& LY3298176 \\
& NN9709/MAR709/RG7697 \\
GLP-1R/GIPR & SAR438335 \\
& ZP-I-98 \\
& ZP-DI-70 \\
& HM15211 \\
GLP-1R/GCGR/GIPR & MAR423 \\
\hline \hline
\end{tabular}

$$
\begin{aligned}
& \text { http://joe.endocrinology-journals.org } \\
& \text { https://doi.org/10.1530/JOE-18-0264 }
\end{aligned}
$$

(๑) 2018 The authors Published by Bioscientifica Ltd. Printed in Great Britain
(Table 1). Undoubtedly, more information on the clinical effects of these drugs will be available soon.

\section{GLP-1/GIP co-agonism}

GIP is a 42 amino acid protein secreted by the enteroendocrine K-cells of the proximal small intestine in response to nutrient intake (Drucker 2006). As an incretin hormone, the primary role of GIP is to stimulate insulin secretion (Fig. 1). Treatment with GIP is reported to normalize blood glucose and to improve glucose tolerance (Hinke et al. 2002, Gault et al. 2011, Kim et al. 2012), although its insulinotropic effects are blunted in some individuals with type 2 diabetes (Vilsboll et al. 2002). Despite its glycemic benefits, GIP was dismissed as a potential anti-obesity target due to some reports testifying GIP is obesogenic in nature in mice and certain cell lines (Eckel et al. 1979, Oben et al. 1991, Miyawaki et al. 2002, McClean et al. 2007, Althage et al. 2008, Gogebakan et al. 2012, Finan et al. 2016). However, more recent studies demonstrate that chronic treatment with GIP can decrease body weight in rodents (Finan et al. 2016). Mice overexpressing GIP show improved glycemic control and resistance to diet-induced obesity (Kim et al. 2012). Chronic GIPR agonism further improves glucose metabolism in DIO mice without signs of excess weight gain (Martin et al. 2013). Transgenic pigs expressing a dominant negative GIP receptor in the pancreas also show impaired glucose tolerance due to delayed insulin secretion, impaired insulinotropic action of GIP, roughly $60 \%$ reduced $\beta$-cell proliferation and reduced islet mass of up to $58 \%$ at the age of 1 year (Renner et al. 2010).

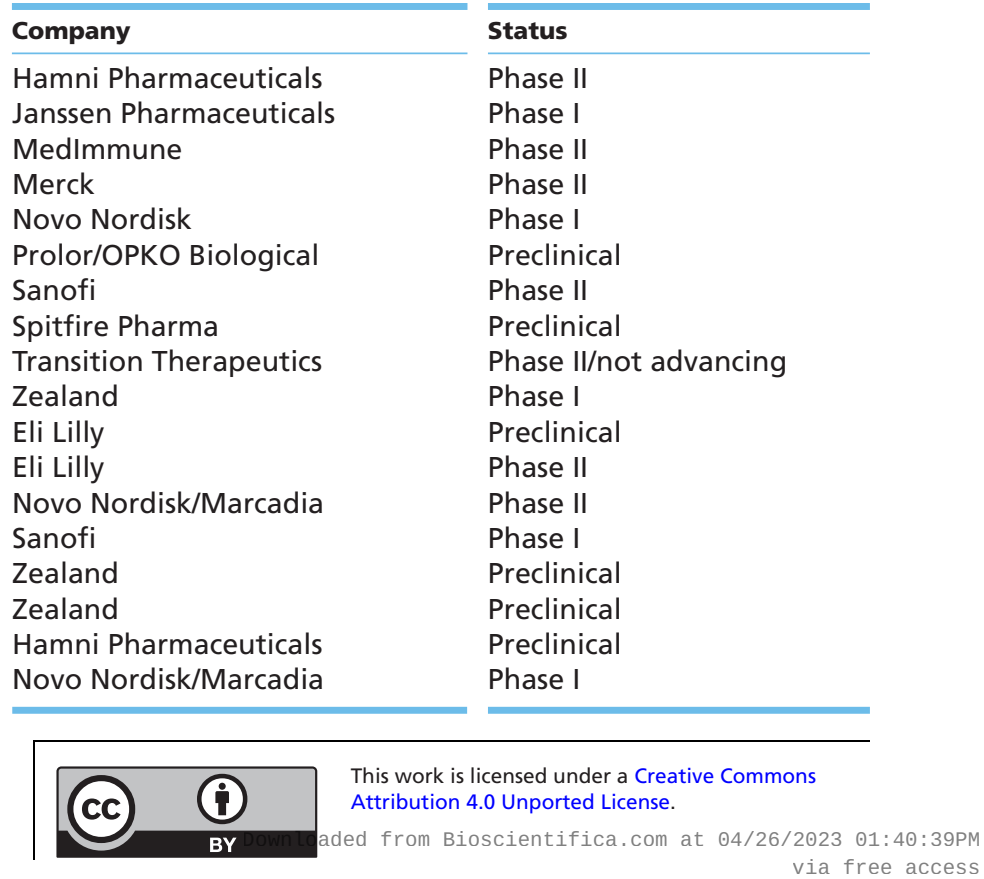


The rationale to combine the pharmacology of GLP-1 and GIP in a single entity was based on the hypothesis that such a dual incretin hormone action would maximize the glycemic benefits while the anorexigenic effect of GLP-1 would restrain any obesogenic potential of GIP (Fig. 3). In support of this hypothesis, co-administration of GLP-1 and GIP in mice was a priori confirmed to improve glycemia and body weight loss in DIO mice (Finan et al. 2013).

Two unimolecular dual incretin ('twincretin') hormones were subsequently created based on the primary glucagon sequence. The dual-agonists incorporated key GLP-1 and GIP residues such that the peptide activated both the GLP-1R and GIPR with equal potency in vitro (Finan et al. 2013). Other modifications included an Aib residue at position 2 to increase resistance to DPP-IV cleavage. This peptide was either acylated with a C16:0 fatty acid (acylated version) at Lys40 or PEGylated with $40 \mathrm{kDa}$ PEG at Cys24 (PEGylated version) to prolong in vivo action. The $\mathrm{C}$-terminal ends of the peptides were further modified to carry the CEX tail from exendin-4. Daily administration of $30 \mathrm{nmol} / \mathrm{kg}$ of the unacylated version of the dual agonist in DIO mice over the course of 7 days resulted in a 14\% drop in body weight, greater than a comparable dose of exendin-4 (Finan et al. 2013). A single $30 \mathrm{nmol} / \mathrm{kg}$ dose of the 16-carbon acylated version of the peptide resulted in an $18.8 \%$ body weight drop (Finan et al. 2013). Both versions of the peptide decreased food intake, lowered body weight primarily through the loss of fat mass and decreased blood glucose levels (Finan et al. 2013). The PEGylated version of the peptide yielded similar results with less frequent dosing (Finan et al. 2013). Like the GLP-1R/GCGR co-agonist, this GLP-1R/GIPR co-agonist has the potential to be an effective weight-loss drug.

The acylated GLP-1R/GIPR co-agonist was also investigated in cynomolgus monkeys. Monkeys were given a single $10 \mathrm{nmol} / \mathrm{kg}$ injection of the acylated co-agonist, and $24 \mathrm{~h}$ later, a dextrose infusion, during which blood glucose and insulin were measured. The co-agonist lowered blood glucose and increased insulin, both to a greater extent than a matched dose of liraglutide (Finan et al. 2013).

The PEGylated co-agonist has even been investigated in humans. In a cohort of healthy, non-diabetic human subjects, a single injection of 4,8 or $16 \mathrm{mg}$ of the PEGylated co-agonist was followed by a dextrose infusion $72 \mathrm{~h}$ later. The co-agonist decreased blood glucose and increased plasma insulin concentration (Finan et al. 2013). In more a chronic study, 53 patients with type 2 diabetes were given weekly injections of 4, 12, 20 and $30 \mathrm{mg}$ of the PEGylated co-agonist, for 6 weeks. The co-agonist lowered HbA1c in a dose-dependent manner (Finan et al. 2013). The co-agonist was well tolerated, with only mildto-moderate side effects (Finan et al. 2013). A further 13-week Phase II study investigated this compound in patients with type 2 diabetes, with comparisons to placebo and liraglutide treatment. Compared to placebo, treatment with once-daily subcutaneous injections of $1.8 \mathrm{mg}$ of the acylated co-agonist resulted in significant decreases in plasma HbA1c, significant decreases in both fasting and self-reported plasma glucose and a decrease

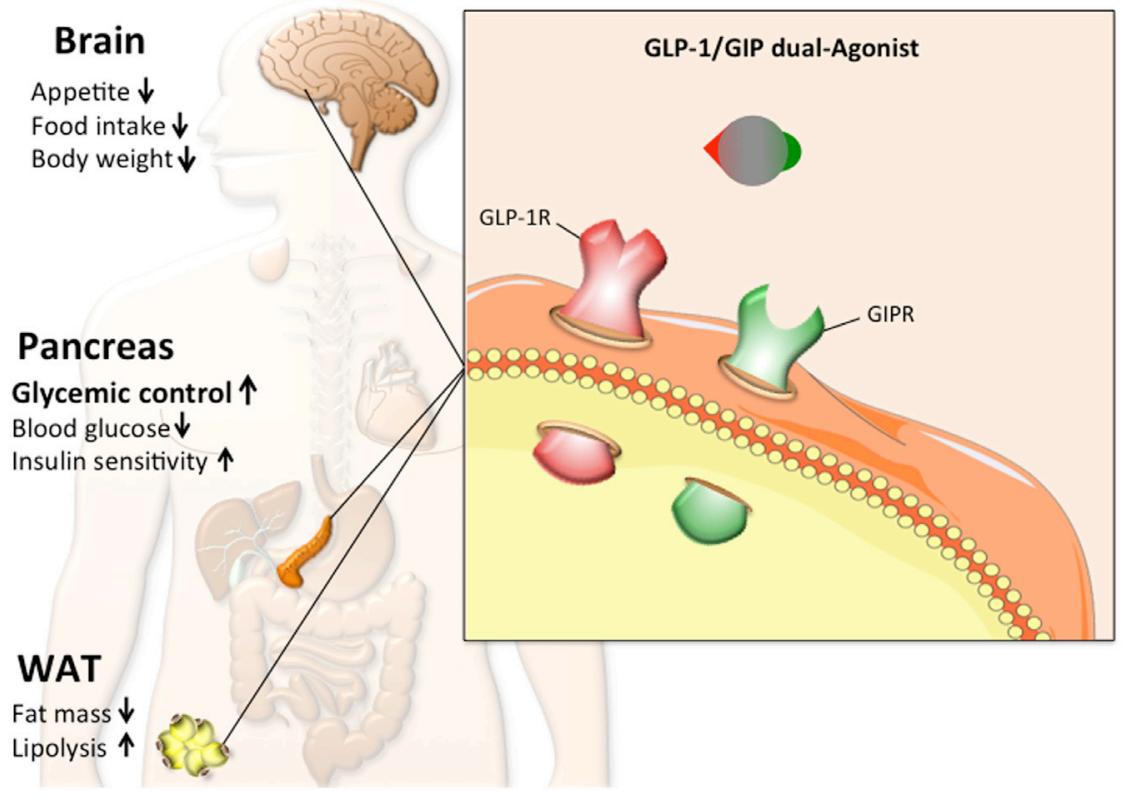

\section{Figure 3}

Schematic demonstrating the working principle, metabolic effects and key target tissues of the GLP-1/GIP dual agonist. Arrows pointing upwards indicate an increase or improvement, while arrows pointing downwards indicate a decrease. The emphasis on glycemic control indicates the relative magnitude of the effect.
() 2018 The authors Published by Bioscientifica Ltd. Printed in Great Britain
This work is licensed under a Creative Commons Attribution 4.0 Unported License.

ded from Bioscientifica.com at 04/26/2023 01:40:39PM 
in body weight that was significant at week 8 but not at week 12 (Frias et al. 2017). Furthermore, treatment with the acylated co-agonist resulted in a significant reduction in total cholesterol, along with a trend in reduction of LDL, triglycerides, free fatty acids and apolipoprotein B (Frias et al. 2017). In the same study, treatment with liraglutide did not result in a change in cholesterol (Frias et al. 2017). Decreases in plasma leptin (22\% relative to placebo) were also observed (Frias et al. 2017), suggesting an increase in leptin sensitivity. In a meal tolerance test, treatment with the compound significantly reduced $2 \mathrm{~h}$ post-prandial glucose (Frias et al. 2017). In terms of safety, there were no serious adverse effects related to treatment. Reported adverse effects were mostly mild to moderate, and the majority were GI-related events (Frias et al. 2017). In addition to these co-agonists, many other GLP-1R/GIPR coagonists are currently in development (Table 1). Whether the promising preclinical results translate into clinical weight-loss benefits remains to be seen.

\section{GLP-1/GIP/glucagon tri-agonist}

The preclinical results of the dual GLP-1-based agonists naturally suggest the combination of all three peptides as a potential unimolecular therapy. It was hypothesized that the dual insulinotropic effect of GLP-1 and GIP would optimally buffer against the diabetogenic liability of glucagon while combined agonism at the receptors for GLP-1 and glucagon would restrain any potential obesogenic effect of GIP. The ultimate result of such triple agonism was a profound ability to decrease body weight and to improve glycemic control (Fig. 4).

Beginning with a previously validated GLP-1/ glucagon dual agonist sequence, GIP residues were introduced stepwise to create a peptide with equal in vitro potency at all three receptors and with superior potency relative to all three native peptides (Finan et al. 2015a,b). This peptide also included an Aib residue at position 2 to protect against DPP-IV cleavage and a C16:0 palmitic acid at the Lys10 position to prolong in vivo action (Finan et al. 2015a,b). In DIO mice, a 20-day study of daily subcutaneous injections of as little as $3 \mathrm{nmol} / \mathrm{kg}$ of the triple agonist resulted in a $26.6 \%$ body weight reduction, which was primarily the result of a loss of fat mass (Finan et al. 2015a,b). In addition, the triple agonist lowered ad libitum blood glucose, improved glucose tolerance and lowered circulating insulin levels (Finan et al. 2015a,b), suggesting improved insulin sensitivity. The triple agonist also lowered hepatic lipid content (Finan et al. 2015a,b), which would be beneficial in a translational setting for patients with fatty liver disease and non-alcoholic steatohepatitis (NASH). Importantly, the metabolic benefits of the triple agonist are dependent on signaling at all three target receptors (Finan et al. $2015 a, b)$, demonstrating that it is truly the triple agonism responsible for the observed benefits. The efficacy of the triple agonist has also been investigated in female mice. The triagonist was equally efficacious in lowering body weight in DIO female mice compared to fat mass matched male mice (Jall et al. 2017). In addition, with a daily dose of $10 \mathrm{nmol} / \mathrm{kg}$ for 27 days, the triagonist largely resolved the hepatosteatosis observed in the female mice

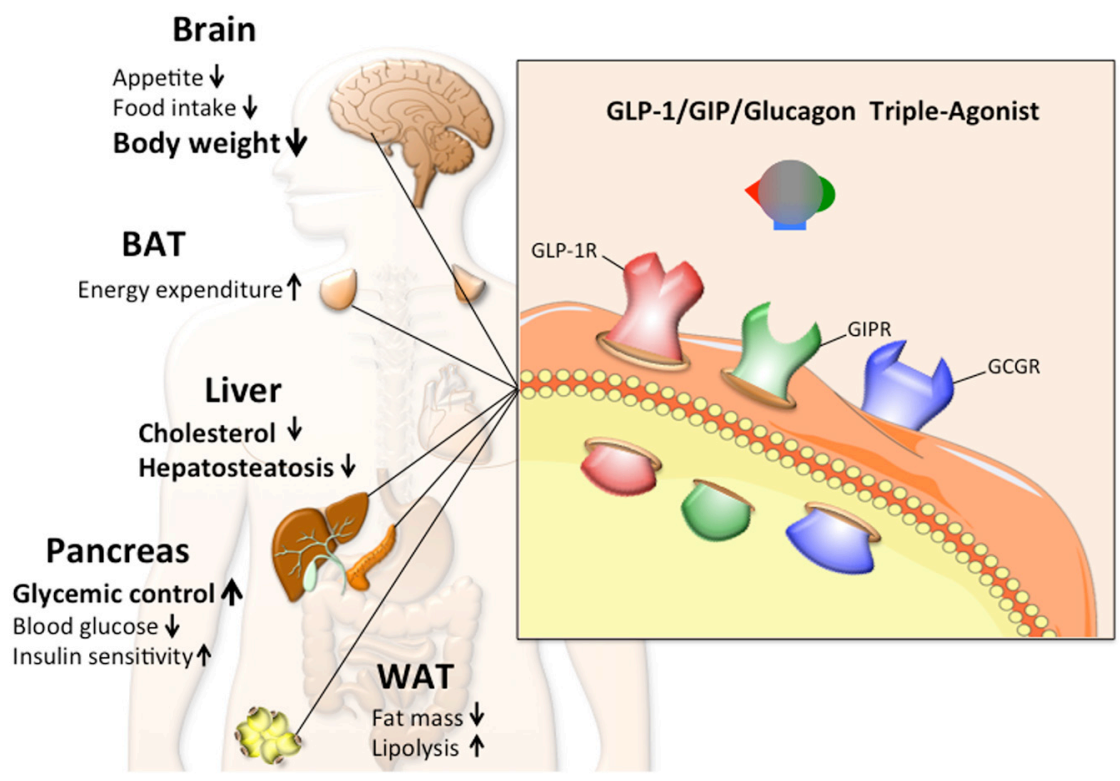

Figure 4

Schematic demonstrating the working principle, metabolic effects and key target tissues of the GLP-1/GIP/glucagon triple agonist, with the size of the text weighted to indicate the magnitude of the observed effect. Arrows pointing upwards indicate an increase or improvement, while arrows pointing downwards indicate a decrease. The triagonist most predominately affects body weight, glycemic control and liver cholesterol and hepatosteatosis. http://joe.endocrinology-journals.org https://doi.org/10.1530/JOE-18-0264
(C) 2018 The authors Published by Bioscientifica Ltd. Printed in Great Britain

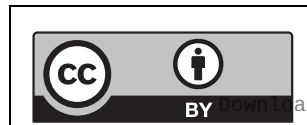

This work is licensed under a Creative Commons Attribution 4.0 Unported License. 
(Jalletal.2017). Unsurprisingly, the triagonist had only mild effects on glucose tolerance in female mice, since female mice are inherently protected against the development of hyperglycemia and hyperinsulinemia. However, the triagonist did resolve the mild hyperinsulinemia observed in the female mice (Jall et al. 2017). Taken together, these results suggest that the triagonist has translational potential in both sexes.

Other triple GLP-1R/GCGR/GIPR agonists are in development (Table 1). Hamni Pharmaceuticals has developed a glucagon-based triple agonist, HM15211, with equal potency at all three receptors in vitro (Choi et al. 2017, Kim et al. 2017). This triple agonist lowers body weight in DIO mice to a greater extent than liraglutide alone and also improves lipid metabolism and hepatic steatosis (Choi et al. 2017, Kim et al. 2017).

A third example, Syn-GIP-ZP, is a triple agonist created by fusing a GLP-1R/GCGR dual agonist and a GIP analog to the heavy and light chains of Synagis, an antibody with low immunogenicity in humans (Wang et al. 2016). This fusion peptide has agonism at all three receptors (Wang et al. 2016) and demonstrates that multiagonism is not necessarily limited to structurally related peptides, but can be achieved through fusion to larger biomolecules. Naturally, the advantages of this approach are the increased synthetic flexibility and enhanced pharmacokinetics; however, these molecules must be carefully engineered for stability and carefully designed so that the ratio of agonism between components is metabolically beneficial.

\section{Are multiagonist peptides the golden therapy for obesity?}

Until now, most anti-obesity drugs have been focused either on singular molecular targets or their loose combination in a co-mixture. Unfortunately, none of these strategies has so far led to satisfactory results. While most historic pharmacotherapies are hampered by an unfavorable imbalance between efficacy and safety, this new class of multiagonist drugs has emerged with candidates that may finally close the gap between the efficacy seen with bariatric surgery and pharmacology. Whereas these multiagonist peptides outperform available best in class drugs to treat obesity, only time will tell if they really represent an appreciable step forward. The available preclinical data are encouraging. However, whether the efficacy and tolerability that has been demonstrated in rodents and monkeys also translates to humans remains to be seen. More long-term studies and outpatient trials are required to determine sustainability and safety. While a final judgment requires more long-term clinical studies, we can be carefully optimistic that this new class of specially engineered drugs is lighting the path to a new era in weight-loss pharmacology.

\section{Declaration of interest}

S J B, M K and T D M declare that there is no conflict of interest that could be perceived as prejudicing the impartiality of this review. M H T is a scientific advisor for Novo Nordisk and Erx Biotech.

\section{Funding}

This work was supported in part by funding to $\mathrm{M} \mathrm{H} \mathrm{T}$ from the Alexander von Humboldt Foundation, the Helmholtz Alliance ICEMED \& the Helmholtz Initiative on Personalized Medicine iMed by Helmholtz Association and the Helmholtz cross-program topic 'Metabolic Dysfunction.' This work was further supported by grants from the German Research Foundation DFG-TS226/1-1, DFG-TS226/3-1, European Research Council ERC AdG HypoFlam no. 695054 and the German Center for Diabetes Research (DZD e.V.).

\section{Acknowledgements}

The figures were made using material provided by Servier Medical Art (Servier), under the terms of the Creative Commons Attribution 3.0 Unported License.

\section{Author contribution statement}

S J B and T D M conceptualized the project and wrote the manuscript. $\mathrm{M} \mathrm{K}$ and $\mathrm{M} \mathrm{H} \mathrm{T}$ co-conceptualized the manuscript and edited the manuscript.

\section{References}

1992 Gastrointestinal surgery for severe obesity: National Institutes of Health Consensus Development Conference Statement. American Journal of Clinical Nutrition 55 615S-619S.

Afshin A, Forouzanfar MH, Reitsma MB, Sur P, Estep K, Lee A, Marczak L, Mokdad AH, Moradi-Lakeh M, Naghavi M, et al. 2017 Health effects of overweight and obesity in 195 countries over 25 years. New England Journal of Medicine 377 13-27. (https://doi.org/10.1056/ NEJMoa1614362)

Althage MC, Ford EL, Wang S, Tso P, Polonsky KS \& Wice BM 2008 Targeted ablation of glucose-dependent insulinotropic polypeptideproducing cells in transgenic mice reduces obesity and insulin resistance induced by a high fat diet. Journal of Biological Chemistry 283 18365-18376. (https://doi.org/10.1074/jbc.M710466200)

Baggio LL \& Drucker DJ 2007 Biology of incretins: GLP-1 and GIP. Gastroenterology 132 2131-2157. (https://doi.org/10.1053/j. gastro.2007.03.054)

Bayham BE, Greenway FL, Bellanger DE \& O'Neil CE 2012 Early resolution of type 2 diabetes seen after Roux-en-Y gastric bypass and vertical sleeve gastrectomy. Diabetes Technology and Therapeutics 14 30-34. (https://doi.org/10.1089/dia.2011.0151)

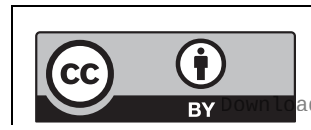

This work is licensed under a Creative Commons Attribution 4.0 Unported License. 
Bergenstal RM, Wysham C, Macconell L, Malloy J, Walsh B, Yan P, Wilhelm K, Malone J, Porter LE \& DURATION-2 Study Group 2010 Efficacy and safety of exenatide once weekly versus sitagliptin or pioglitazone as an adjunct to metformin for treatment of type 2 diabetes (DURATION-2): a randomised trial. Lancet 376 431-439. (https://doi.org/10.1016/S0140-6736(10)60590-9)

Brolin RE, Robertson LB, Kenler HA \& Cody RP 1994 Weight loss and dietary intake after vertical banded gastroplasty and Roux-en-Y gastric bypass. Annals of Surgery 220 782-790. (https://doi.org/10.1097/00000658-199412000-00012)

Buchwald H 2002 A bariatric surgery algorithm. Obesity Surgery 12 733-746; discussion 747-750. (https://doi. org/10.1381/096089202320995484)

Buchwald H, Avidor Y, Braunwald E, Jensen MD, Pories W, Fahrbach K \& Schoelles K 2004 Bariatric surgery: a systematic review and meta-analysis. JAMA 292 1724-1737. (https://doi.org/10.1001/ jama.292.14.1724)

Burge JC, Schaumburg JZ, Choban PS, DiSilvestro RA \& Flancbaum L 1995 Changes in patients' taste acuity after Roux-en-Y gastric bypass for clinically severe obesity. Journal of the American Dietetic Association 95 666-670. (https://doi.org/10.1016/S00028223(95)00182-4)

Bush MA, Matthews JE, De Boever EH, Dobbins RL, Hodge RJ, Walker SE, Holland MC, Gutierrez M \& Stewart MW 2009 Safety, tolerability, pharmacodynamics and pharmacokinetics of albiglutide, a longacting glucagon-like peptide- 1 mimetic, in healthy subjects. Diabetes, Obesity and Metabolism 11 498-505. (https://doi.org/10.1111/j.14631326.2008.00992.x)

Butler PC \& Rizza RA 1991 Contribution to postprandial hyperglycemia and effect on initial splanchnic glucose clearance of hepatic glucose cycling in glucose-intolerant or NIDDM patients. Diabetes 40 73-81. (https://doi.org/10.2337/diab.40.1.73)

Carswell KA, Vincent RP, Belgaumkar AP, Sherwood RA, Amiel SA, Patel AG \& le Roux CW 2014 The effect of bariatric surgery on intestinal absorption and transit time. Obesity Surgery 24 796-805. (https://doi.org/10.1007/s11695-013-1166-x)

Chabenne JR, DiMarchi MA, Gelfanov VM \& DiMarchi RD 2010 Optimization of the native glucagon sequence for medicinal purposes. Journal of Diabetes Science and Technology 4 1322-1331. (https://doi. org/10.1177/193229681000400605)

Chang SH, Stoll CR, Song J, Varela JE, Eagon CJ \& Colditz GA 2014 The effectiveness and risks of bariatric surgery: an updated systematic review and meta-analysis, 2003-2012. JAMA Surgery 149 275-287. (https://doi.org/10.1001/jamasurg.2013.3654)

Choi IY, Lee JS, Kim JK, Park YJ, Jung SY, Kim YH \& Kwon SC 2017 Potent body weight loss and efficacy in a NASH animal model by a novel long-acting GLP-1/Glucagon/GIP triple-agonist (HM15211). In American Diabetes Association's 77th Scientific Session, San Diego, CA, USA.

Clemmensen C, Muller TD, Woods SC, Berthoud HR, Seeley RJ \& Tschop MH 2017 Gut-brain cross-talk in metabolic control. Cell 168 758-774. (https://doi.org/10.1016/j.cell.2017.01.025)

Davies MJ, Bergenstal R, Bode B, Kushner RF, Lewin A, Skjøth TV, Andreasen AH, Jensen CB, DeFronzo RA \& NN8022-1922 Study Group 2015 Efficacy of liraglutide for weight loss among patients with type 2 diabetes: the SCALE Diabetes Randomized Clinical Trial. JAMA 314 687-699. (https://doi.org/10.1001/jama.2015.9676)

Day JW, Ottaway N, Patterson JT, Gelfanov V, Smiley D, Gidda J, Findeisen H, Bruemmer D, Drucker DJ, Chaudhary N, et al. 2009 A new glucagon and GLP-1 co-agonist eliminates obesity in rodents. Nature Chemical Biology 5 749-757. (https:/doi.org/10.1038/ nchembio.209)

Deacon CF, Johnsen AH \& Holst JJ 1995 Degradation of glucagon-like peptide- 1 by human plasma in vitro yields an $\mathrm{N}$-terminally truncated peptide that is a major endogenous metabolite in vivo. Journal of Clinical Endocrinology and Metabolism 80 952-957
Drucker DJ 2006 The biology of incretin hormones. Cell Metabolism 3 153-165. (https://doi.org/10.1016/j.cmet.2006.01.004)

Dungan KM, Weitgasser R, Perez Manghi F, Pintilei E, Fahrbach JL, Jiang HH, Shell J \& Robertson KE 2016 A 24-week study to evaluate the efficacy and safety of once-weekly dulaglutide added on to glimepiride in type 2 diabetes (AWARD-8). Diabetes, Obesity and Metabolism 18 475-482. (https://doi.org/10.1111/dom.12634)

Eckel RH, Fujimoto WY \& Brunzell JD 1979 Gastric inhibitory polypeptide enhanced lipoprotein lipase activity in cultured preadipocytes. Diabetes 28 1141-1142. (https://doi.org/10.2337/ diab.28.12.1141)

Evers A, Haack T, Lorenz M, Bossart M, Elvert R, Henkel B, Stengelin S, Kurz M, Glien M, Dudda A, et al. 2017 Design of novel exendin-based dual glucagon-like peptide 1 (GLP-1)/glucagon receptor agonists. Journal of Medicinal Chemistry 60 4293-4303. (https://doi.org/10.1021/ acs.jmedchem.7b00174)

Felig P, Wahren J \& Hendler R 1978 Influence of maturity-onset diabetes on splanchnic glucose balance after oral glucose ingestion. Diabetes 27 121-126. (https://doi.org/10.2337/diab.27.2.121)

Finan B, Ma T, Ottaway N, Müller TD, Habegger KM, Heppner KM, Kirchner H, Holland J, Hembree J, Raver C, et al. 2013 Unimolecular dual incretins maximize metabolic benefits in rodents, monkeys, and humans. Science Translational Medicine 5 209ra151

Finan B, Yang B, Ottaway N, Smiley DL, Ma T, Clemmensen C, Chabenne J, Zhang L, Habegger KM, Fischer K, et al. 2015a A rationally designed monomeric peptide triagonist corrects obesity and diabetes in rodents. Nature Medicine 21 27-36. (https://doi. org/10.1038/nm.3761)

Finan B, Clemmensen C \& Muller TD 2015b Emerging opportunities for the treatment of metabolic diseases: glucagon-like peptide-1 based multi-agonists. Molecular and Cellular Endocrinology 418 42-54. (https://doi.org/10.1016/j.mce.2015.07.003)

Finan B, Muller TD, Clemmensen C, Perez-Tilve D, DiMarchi RD \& Tschop MH 2016 Reappraisal of GIP pharmacology for metabolic diseases. Trends in Molecular Medicine 22 359-376. (https://doi. org/10.1016/j.molmed.2016.03.005)

Frias JP, Bastyr EJ, 3rd, Vignati L, Tschöp MH, Schmitt C, Owen K, Christensen RH \& DiMarchi RD 2017 The sustained effects of a dual GIP/GLP-1 receptor agonist, NNC0090-2746, in patients with type 2 diabetes. Cell Metabolism 26 343.e342-352.e342. (https://doi. org/10.1016/j.cmet.2017.07.011)

Gault VA, Porter DW, Irwin N \& Flatt PR 2011 Comparison of sub-chronic metabolic effects of stable forms of naturally occurring GIP(1-30) and GIP(1-42) in high-fat fed mice. Journal of Endocrinology 208 265-271

Fonseca VA, Alvarado-Ruiz R, Raccah D, Boka G, Miossec P, Gerich JE \& EFC6018 GetGoal-Mono Study Investigators 2012 Efficacy and safety of the once-daily GLP-1 receptor agonist lixisenatide in monotherapy: a randomized, double-blind, placebo-controlled trial in patients with type 2 diabetes (GetGoal-Mono). Diabetes Care 35 1225-1231. (https://doi.org/10.2337/dc11-1935)

Gerich JE, Langlois M, Noacco C, Lorenzi M, Karam JH \& Korsham PH 1976 Comparison of the suppressive effects of elevated plasma glucose and free fatty acid levels on glucagon secretion in normal and insulin-dependent diabetic subjects. Evidence for selective alphacell insensitivity to glucose in diabetes mellitus. Journal of Clinical Investigation 58 320-325. (https://doi.org/10.1172/JCI108475)

Gogebakan O, Andres J, Biedasek K, Mai K, Kühnen P, Krude H, Isken F, Rudovich N, Osterhoff MA, Kintscher U, et al. 2012 Glucosedependent insulinotropic polypeptide reduces fat-specific expression and activity of 11beta-hydroxysteroid dehydrogenase type 1 and inhibits release of free fatty acids. Diabetes 61 292-300. (https://doi. org/10.2337/db10-0902)

Henderson SJ, Konkar A, Hornigold DC, Trevaskis JL, Jackson R, Fritsch Fredin M, Jansson-Löfmark R, Naylor J, Rossi A, Bednarek MA, et al. 2016 Robust anti-obesity and metabolic effects of a dual GLP-1/ glucagon receptor peptide agonist in rodents and non-human

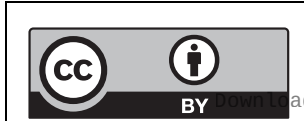

This work is licensed under a Creative Common Attribution 4.0 Unported License. 
primates. Diabetes, Obesity and Metabolism 18 1176-1190. (https://doi. org/10.1111/dom.12735)

Hinke SA, Gelling RW, Pederson RA, Manhart S, Nian C, Demuth HU \& McIntosh CH 2002 Dipeptidyl peptidase IV-resistant [D-Ala(2)] glucose-dependent insulinotropic polypeptide (GIP) improves glucose tolerance in normal and obese diabetic rats. Diabetes 51 652-661. (https://doi.org/10.2337/diabetes.51.3.652)

Hui H, Farilla L, Merkel P \& Perfetti R 2002 The short half-life of glucagon-like peptide-1 in plasma does not reflect its long-lasting beneficial effects. European Journal of Endocrinology 146 863-869. (https://doi.org/10.1530/eje.0.1460863)

Jall S, Sachs S, Clemmensen C, Finan B, Neff F, DiMarchi RD, Tschöp MH, Müller TD \& Hofmann SM 2017 Monomeric GLP-1/GIP/glucagon triagonism corrects obesity, hepatosteatosis, and dyslipidemia in female mice. Molecular Metabolism 6 440-446. (https://doi. org/10.1016/j.molmet.2017.02.002)

Kelley D, Mokan M \& Veneman T 1994 Impaired postprandial glucose utilization in non-insulin-dependent diabetes mellitus. Metabolism 43 1549-1557. (https://doi.org/10.1016/0026-0495(94)90015-9)

Kieffer TJ, McIntosh CH \& Pederson RA 1995 Degradation of glucosedependent insulinotropic polypeptide and truncated glucagon-like peptide 1 in vitro and in vivo by dipeptidyl peptidase IV. Endocrinology 136 3585-3596. (https://doi.org/10.1210/endo.136.8.7628397)

Kim SJ, Nian C, Karunakaran S, Clee SM, Isales CM \& McIntosh CH 2012 GIP-overexpressing mice demonstrate reduced diet-induced obesity and steatosis, and improved glucose homeostasis. PLoS ONE 7 e40156. (https://doi.org/10.1371/journal.pone.0040156)

Kim JA, Lee SH, Choi IY, Kim YH, Lee YM \& Kwon SC 2017 Neuroprotective effects of HM15211, a novel long-acting GLP-1/ glucagon/GIP triple agonist in the MPTP Parkinson's disease mouse model. In American Diabetes Association's 77th Scientific Sessions, San Diego, CA, USA.

Laferrere B 2016 Bariatric surgery and obesity: influence on the incretins. International Journal of Obesity Supplements 6 S32-S36. (https://doi. org/10.1038/ijosup.2016.8)

Lau J, Bloch P, Schaffer L, Pettersson I, Spetzler J, Kofoed J, Madsen K, Knudsen LB, McGuire J, Steensgaard DB, et al. 2015 Discovery of the once-weekly glucagon-like peptide-1 (GLP-1) analogue semaglutide. Journal of Medicinal Chemistry 58 7370-7380. (https://doi.org/10.1021/ acs.jmedchem.5b00726)

Laurenius A, Larsson I, Bueter M, Melanson KJ, Bosaeus I, Forslund HB, Lönroth H, Fändriks L \& Olbers T 2012 Changes in eating behaviour and meal pattern following Roux-en-Y gastric bypass. International Journal of Obesity 36 348-355. (https://doi.org/10.1038/ijo.2011.217)

Laurenius A, Larsson I, Melanson KJ, Lindroos AK, Lönroth H, Bosaeus I \& Olbers T 2013 Decreased energy density and changes in food selection following Roux-en-Y gastric bypass. European Journal of Clinical Nutrition 67 168-173. (https://doi.org/10.1038/ejcn.2012.208)

Li P, Rogers T, Smiley D, DiMarchi RD \& Zhang F 2007 Design, synthesis and crystallization of a novel glucagon analog as a therapeutic agent. Acta Crystallographica, Section F: Structural Biology and Crystallization Communications 63 599-601. (https://doi.org/10.1107/ S1744309107028655)

MacLean PS, Higgins JA, Giles ED, Sherk VD \& Jackman MR 2015 The role for adipose tissue in weight regain after weight loss. Obesity Reviews 16 (Supplement 1) 45-54.

Martin CM, Irwin N, Flatt PR \& Gault VA 2013 A novel acylated form of (d-Ala(2))GIP with improved antidiabetic potential, lacking effect on body fat stores. Biochimica et Biophysica Acta $18303407-3413$. (https://doi.org/10.1016/j.bbagen.2013.03.011)

Mathes CM \& Spector AC 2012 Food selection and taste changes in humans after Roux-en-Y gastric bypass surgery: a direct-measures approach. Physiology and Behavior 107 476-483. (https://doi. org/10.1016/j.physbeh.2012.02.013)

McClean PL, Irwin N, Cassidy RS, Holst JJ, Gault VA \& Flatt PR 2007 GIP receptor antagonism reverses obesity, insulin resistance, and associated metabolic disturbances induced in mice by prolonged consumption of high-fat diet. American Journal of Physiology: Endocrinology and Metabolism 293 E1746-E1755. (https://doi. org/10.1152/ajpendo.00460.2007)

Meek CL, Lewis HB, Reimann F, Gribble FM \& Park AJ 2016 The effect of bariatric surgery on gastrointestinal and pancreatic peptide hormones. Peptides 77 28-37. (https://doi.org/10.1016/j. peptides.2015.08.013)

Meier JJ 2012 GLP-1 receptor agonists for individualized treatment of type 2 diabetes mellitus. Nature Reviews Endocrinology 8 728-742. (https://doi.org/10.1038/nrendo.2012.140)

Mentlein R, Gallwitz B \& Schmidt WE 1993 Dipeptidyl-peptidase IV hydrolyses gastric inhibitory polypeptide, glucagon-like peptide-1(7-36)amide, peptide histidine methionine and is responsible for their degradation in human serum. European Journal of Biochemistry 214 829-835. (https://doi.org/10.1111/j.1432-1033.1993. tb17986.x)

Miras AD \& le Roux CW 2010 Bariatric surgery and taste: novel mechanisms of weight loss. Current Opinion in Gastroenterology 26 140-145. (https://doi.org/10.1097/MOG.0b013e328333e94a)

Miyawaki K, Yamada Y, Ban N, Ihara Y, Tsukiyama K, Zhou H, Fujimoto S, Oku A, Tsuda K, Toyokuni S, et al. 2002 Inhibition of gastric inhibitory polypeptide signaling prevents obesity. Nature Medicine $\mathbf{8}$ 738-742. (https://doi.org/10.1038/nm727)

Muller WA, Faloona GR, Aguilar-Parada E \& Unger RH 1970 Abnormal alpha-cell function in diabetes. Response to carbohydrate and protein ingestion. New England Journal of Medicine 283 109-115. (https://doi. org/10.1056/NEJM197007162830301)

Muller TD, Finan B, Clemmensen C, DiMarchi RD \& Tschop MH 2017 The new biology and pharmacology of glucagon. Physiological Reviews 97 721-766. (https://doi.org/10.1152/physrev.00025.2016)

Munzberg H, Laque A, Yu S, Rezai-Zadeh K \& Berthoud HR 2015 Appetite and body weight regulation after bariatric surgery. Obesity Reviews 16 (Supplement 1) 77-90. (https://doi.org/10.1111/obr.12258)

Nauck M, Frid A, Hermansen K, Shah NS, Tankova T, Mitha IH, Zdravkovic M, Düring M, Matthews DR \& LEAD-2 Study Group 2009 Efficacy and safety comparison of liraglutide, glimepiride, and placebo, all in combination with metformin, in type 2 diabetes: the LEAD (liraglutide effect and action in diabetes)-2 study. Diabetes Care 32 84-90. (https://doi.org/10.2337/dc08-1355)

Nauck MA, Petrie JR, Sesti G, Mannucci E, Courrèges JP, Lindegaard ML, Jensen CB, Atkin SL \& Study 1821 Investigators 2016 A phase 2, randomized, dose-finding study of the novel once-weekly human GLP-1 analog, semaglutide, compared with placebo and openlabel liraglutide in patients with type 2 diabetes. Diabetes Care 39 231-241

Neidigh JW, Fesinmeyer RM, Prickett KS \& Andersen NH 2001 Exendin-4 and glucagon-like-peptide-1: NMR structural comparisons in the solution and micelle-associated states. Biochemistry $4013188-13200$. (https://doi.org/10.1021/bi010902s)

Oben J, Morgan L, Fletcher J \& Marks V 1991 Effect of the enteropancreatic hormones, gastric inhibitory polypeptide and glucagonlike polypeptide-1(7-36) amide, on fatty acid synthesis in explants of rat adipose tissue. Journal of Endocrinology 130 267-272. (https://doi. org/10.1677/joe.0.1300267)

Odstrcil EA, Martinez JG, Santa Ana CA, Xue B, Schneider RE, Steffer KJ, Porter JL, Asplin J, Kuhn JA \& Fordtran JS 2010 The contribution of malabsorption to the reduction in net energy absorption after longlimb Roux-en-Y gastric bypass. American Journal of Clinical Nutrition 92 704-713. (https://doi.org/10.3945/ajcn.2010.29870)

Olbers T, Bjorkman S, Lindroos A, Maleckas A, Lönn L, Sjöström L \& Lönroth H 2006 Body composition, dietary intake, and energy expenditure after laparoscopic Roux-en-Y gastric bypass and laparoscopic vertical banded gastroplasty: a randomized clinical trial. Annals of Surgery 244 715-722. (https://doi.org/10.1097/01. sla.0000218085.25902.f8)

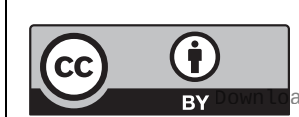

This work is licensed under a Creative Commons Attribution 4.0 Unported License.

ded from Bioscientifica.com at 04/26/2023 01:40:39PM 
Peterli R, Wolnerhanssen B, Peters T, Devaux N, Kern B, ChristoffelCourtin C, Drewe J, von Flüe M \& Beglinger C 2009 Improvement in glucose metabolism after bariatric surgery: comparison of laparoscopic Roux-en-Y gastric bypass and laparoscopic sleeve gastrectomy: a prospective randomized trial. Annals of Surgery $\mathbf{2 5 0}$ 234-241. (https://doi.org/10.1097/SLA.0b013e3181ae32e3)

Pocai A 2014 Action and therapeutic potential of oxyntomodulin. Molecular Metabolism 3 241-251. (https://doi.org/10.1016/j. molmet.2013.12.001)

Pocai A, Carrington PE, Adams JR, Wright M, Eiermann G, Zhu L, Du X, Petrov A, Lassman ME, Jiang G, et al. 2009 Glucagon-like peptide 1/ glucagon receptor dual agonism reverses obesity in mice. Diabetes $\mathbf{5 8}$ 2258-2266. (https://doi.org/10.2337/db09-0278)

Pories WJ, Swanson MS, MacDonald KG, Long SB, Morris PG, Brown BM, Barakat HA, deRamon RA, Israel G, Dolezal JM, et al. 1995 Who would have thought it? An operation proves to be the most effective therapy for adult-onset diabetes mellitus. Annals of Surgery 222 339-350; discussion 350-332. (https://doi.org/10.1097/00000658-19950900000011)

Pratley RE, Aroda VR, Lingvay I, Lüdemann J, Andreassen C, Navarria A, Viljoen A \& SUSTAIN 7 investigators 2018 Semaglutide versus dulaglutide once weekly in patients with type 2 diabetes (SUSTAIN 7): a randomised, open-label, phase $3 \mathrm{~b}$ trial. Lancet Diabetes and Endocrinology 6 275-286. (https://doi.org/10.1016/S22138587(18)30024-X)

Renner S, Fehlings C, Herbach N, Hofmann A, von Waldthausen DC, Kessler B, Ulrichs K, Chodnevskaja I, Moskalenko V, Amselgruber W, et al. 2010 Glucose intolerance and reduced proliferation of pancreatic beta-cells in transgenic pigs with impaired glucosedependent insulinotropic polypeptide function. Diabetes $\mathbf{5 9}$ 1228-1238. (https://doi.org/10.2337/db09-0519)

Rosenstock J, Raccah D, Koranyi L, Maffei L, Boka G, Miossec P \& Gerich JE 2013 Efficacy and safety of lixisenatide once daily versus exenatide twice daily in type 2 diabetes inadequately controlled on metformin: a 24-week, randomized, open-label, active-controlled study (GetGoal-X). Diabetes Care 36 2945-2951. (https://doi. org/10.2337/dc12-2709)

Russell-Jones D, Cuddihy RM, Hanefeld M, Kumar A, González JG, Chan M, Wolka AM, Boardman MK \& DURATION-4 Study Group 2012 Efficacy and safety of exenatide once weekly versus metformin, pioglitazone, and sitagliptin used as monotherapy in drug-naive patients with type 2 diabetes (DURATION-4): a 26-week doubleblind study. Diabetes Care 35 252-258. (https://doi.org/10.2337/ dc11-1107)

Ryan KK, Tremaroli V, Clemmensen C, Kovatcheva-Datchary P, Myronovych A, Karns R, Wilson-Pérez HE, Sandoval DA, Kohli R, Bäckhed F, et al. 2014 FXR is a molecular target for the effects of vertical sleeve gastrectomy. Nature $\mathbf{5 0 9} 183-188$. (https://doi. org/10.1038/nature13135)
Schmidt JB, Pedersen SD, Gregersen NT, Vestergaard L, Nielsen MS, Ritz C, Madsbad S, Worm D, Hansen DL, Clausen TR, et al. 2016 Effects of RYGB on energy expenditure, appetite and glycaemic control: a randomized controlled clinical trial. International Journal of Obesity 40 281-290. (https://doi.org/10.1038/ijo.2015.162)

Scruggs DM, Buffington C \& Cowan GS Jr 1994 Taste acuity of the morbidly obese before and after gastric bypass surgery. Obesity Surgery 4 24-28. (https://doi.org/10.1381/096089294765558854)

Shin AC \& Berthoud HR 2011 Food reward functions as affected by obesity and bariatric surgery. International Journal of Obesity $\mathbf{3 5}$ (Supplement 3) S40-44. (https://doi.org/10.1038/ijo.2011.147)

Sisley S, Gutierrez-Aguilar R, Scott M, D'Alessio DA, Sandoval DA \& Seeley RJ 2014 Neuronal GLP1R mediates liraglutide's anorectic but not glucose-lowering effect. Journal of Clinical Investigation $\mathbf{1 2 4}$ 2456-2463. (https://doi.org/10.1172/JCI72434)

Sjostrom L, Lindroos AK, Peltonen M, Torgerson J, Bouchard C, Carlsson B, Dahlgren S, Larsson B, Narbro K, Sjöström CD, et al. 2004 Lifestyle, diabetes, and cardiovascular risk factors 10 years after bariatric surgery. New England Journal of Medicine 351 2683-2693. (https://doi.org/10.1056/NEJMoa035622)

Thompson AM \& Trujillo JM 2015 Dulaglutide: the newest GLP-1 receptor agonist for the management of type 2 diabetes. Annals of Pharmacotherapy 49 351-359. (https://doi. org/10.1177/1060028014564180)

Unger RH \& Cherrington AD 2012 Glucagonocentric restructuring of diabetes: a pathophysiologic and therapeutic makeover. Journal of Clinical Investigation 122 4-12. (https://doi.org/10.1172/JCI60016)

Unger RH, Aguilar-Parada E, Muller WA \& Eisentraut AM 1970 Studies of pancreatic alpha cell function in normal and diabetic subjects. Journal of Clinical Investigation 49 837-848. (https://doi.org/10.1172/ JCI106297)

Vilsboll T, Krarup T, Madsbad S \& Holst JJ 2002 Defective amplification of the late phase insulin response to glucose by GIP in obese Type II diabetic patients. Diabetologia 45 1111-1119. (https://doi. org/10.1007/s00125-002-0878-6)

Wang Y, Du J, Zou H, Liu Y, Zhang Y, Gonzalez J, Chao E, Lu L, Yang P, Parker H, et al. 2016 Multifunctional antibody agonists targeting glucagon-like peptide-1, glucagon, and glucose-dependent insulinotropic polypeptide receptors. Angewandte Chemie International Edition in English 55 12475-12478. (https://doi.org/10.1002/ anie.201606321)

Wells JC 2006 The evolution of human fatness and susceptibility to obesity: an ethological approach. Biological Reviews of the Cambridge Philosophical Society 81 183-205. (https://doi.org/10.1017/ S1464793105006974)

Woodward HN \& Anderson SL 2014 Once-weekly albiglutide in the management of type 2 diabetes: patient considerations. Patient Preference and Adherence 8 789-803. (https://doi.org/10.2147/PPA. S53075)

Received in final form 27 April 2018

Accepted 30 May 2018

Accepted Preprint published online 30 May 2018 http://joe.endocrinology-journals.org https://doi.org/10.1530/JOE-18-0264 (c) 2018 The authors Published by Bioscientifica Ltd. Printed in Great Britain

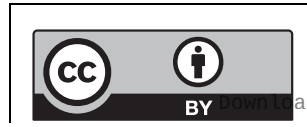

This work is licensed under a Creative Commons Attribution 4.0 Unported License.

ded from Bioscientifica.com at 04/26/2023 01:40:39PM 